cost, ZWO will be allowed to allocate 20 per cent of the observing time to Dutch astronomers. It has not yet been decided precisely how the Netherlands will help to solve the manpower shortage. When the observatory is fully operational, Professor Smith estimates that about 30 technical staff will be needed in La Palma at any one time. The difficulty is in persuading sufficient British scientists to uproot themselves for three years at a time.

ZWO has decided to pay its share out of its existing budget of about $£ 40$ million a year. Most of the money will come from the $£ 6$ million a year now spent on astronomy, implying a major shift in astronomy funding. Although most Dutch astronomers are expected to welcome the agreement, radioastronomers may feel hard done by.

The next step is for Professor van Lieshout, director of ZWO, to obtain the approval of the Dutch minister for science, who is reported to be enthusiastic. But the imminent Dutch election could mean that the issue will have to be decided by a new minister. All being well, however, Professor van Lieshout hopes that an agreement could be signed and sealed within the next four months.

Judy Redfearn

\section{Toxic waste}

\section{Dutch dumps}

\section{Amsterdam}

The cost to the Netherlands of dealing with chemical waste from years of heavy industrialization is mounting. So far about 3,000 dumps containing chemical waste have been found, 500 of them a recognized danger to public health. The Minister for Public Health and Environmental Protection estimated a few months ago that it would cost about $£ 200$ million to clear the 500 dangerous dumps, and this estimate is now $£ 400$ million.

In the village of Lekkerkerk, not far from the heavily concentrated chemical industries of Rotterdam, many buildings were found to have been built on a chemical waste dump. About 1,700 drums were recovered from the site, containing materials such as toluene and xylene from the dye industry and metals such as cadmium, zinc and lead. Some $\mathbf{3 0 0}$ houses were evacuated and 150,000 tons of polluted soil have had to be removed, while medical examinations may yet be carried out on the population. Several more chemical waste dumps have since been found in the same area.

After cases of cattle infertility and the discovery of dead birds, an investigation by the municipal environmental laboratory of Amsterdam has revealed that the Volgermeerpolder, a marshy area 5 miles from the centre of Amsterdam, contains about 10,000 drums of chemical waste from a 2,4,5-T factory previously owned by Philips-Duphar. The factory ceased production in 1969 and was completely dismantled and dumped in the Atlantic, but its waste remained.

According to Dr H. Heida, director of the Amsterdam environmental laboratory, the drums contain a wide range of chemicals, including chlorobenzene and chlorophenol. However, some of the drums are known to contain 2,4,5-T and possibly the dioxin $2,3,7,8$-tetrachlorocyclodibenzo- $p$-dioxin $(2,3,7,8$-TCDD), and it is this latter compound which it is feared may form the real danger.

Analysis of soil, water and livestock and of produce from gardens in the area has revealed the presence of chemicals from the dump in concentrations of tenths to hundredths of milligrammes per kilogramme weight.

However, the future of the dump rests on the problem of clearly identifying $2,3,7,8-T C D D$. Samples from the drums have been analysed by Professor $O$. Hutzinger's team at Amsterdam University

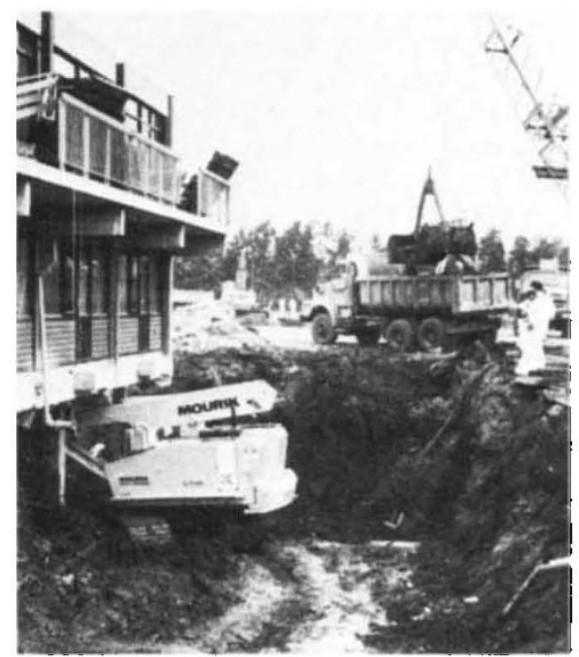

The clearing of Lekkerkerk

and have also been sent to Milan for analysis by the laboratory involved in investigating the Séveso incident. A definite solution to the problem is not expected before the summer.

These pollution scandals prompted a national inventory of chemical waste in the Netherlands due to be completed by the end of 1980 . So far, however, only two of the eleven Dutch provinces have reported their findings.

The problems of the Netherlands have also attracted international interest. Dr David Costle, administrator of the US Environmental Protection Agency, visited the Lekkerkerk dump while he was in the Netherlands to sign a memorandum on cooperation between the two countries. $\mathrm{Dr}$ Tolba of the United Nations Environmental Programme, a regular visitor to the country, is particularly interested in the chemical pollution problems.

The latest revelation was in December of last year, when small amounts of the toxic substance methyl bromide were found in drinking water in the horticultural area between The Hague and Rotterdam. This chemical is used by market gardeners to disinfect the soil, and an estimated 2,000 tons a year are used in this area -30 per cent of the total consumption in the European Community. The poison had apparently seeped through the PVC tubes used for private water distribution. As a result, the Minister for Public Health has made public water supply companies responsible also for private supply pipes. However, it now turns out that PVC tubes are widely used in the Netherlands for transporting water which has been tested for pollutants such as methyl bromide.

Casper Schuuring

\section{Genetic engineering}

\section{Planning bugs}

\section{Washington}

Echoes of the fierce public debates of four years ago are being heard once again in and around Cambridge, Massachusetts, as local city councils discuss the conditions they will place on the genetic engineering companies springing up in their midst.

The tones of the debate are more muted than before. And in each of the four communities - Cambridge, Waltham, Somerville and Newton - the talk this time is of negotiation rather than confrontation. Nevertheless, there is sufficient concern among the companies for the head of at least one to suggest the need for a "more coherent policy" towards local regulation, possible at the state level.

The most significantly affected so far seems to have been Genetics Institute. This is the company which has been set up by $\mathrm{Dr}$ Mark Ptashne, professor of molecular biology at Harvard University, and a local management consultant, Mr Tom Hexner, on privately-raised venture capital, after the Harvard faculty voted against university participation (see Nature 27 November 1980). Its backers include Venrock, a venture capital firm owned by the Rockefeller family, and Mr William Paley of Columbia Broadcasting.

Now the company faces a new hurdle gaining acceptance in the local community. Last November, it applied to build a laboratory in Somerville, just inside the city's border with Cambridge and a few blocks from the university biology laboratories. The application has kindled a fierce public debate. At one point, for example, local citizens had suggested that research should be limited to P1 and P2 physical containment facilities, even stricter than restrictions in Cambridge, which allow work up to the P3 level.

City council members who were originally in favour of granting permission for the new laboratories with few strings attached have backed off in the face of the public controversy; many are preoccupied with severe budget cuts that have resulted from a recent reduction in property taxes.

At a public meeting last Thursday, the 
council agreed to draw up a local ordinance setting out the conditions under which recombinant DNA research can be carried out in the city. Given the uncertainty, Genetics Institute has now withdrawn its application to build the laboratory.

Mr Hexner said last week that there would now inevitably be a delay in the company's plans. "It really depends on how long the deliberations go on and what the tenor of them is; if the tenor is favourable, then we would probably resubmit", he said. An alternative would be to look for a site in Cambridge itself. In sharp contrast with the debates of four years ago, when the then mayor Alfred Velucchi tried to ban all genetic engineering from the city, an ordinance passed in 1977 is being revised in relatively amicable circumstances.

The revisions have been precipitated by the decision of the Geneva-based Biogen Inc. to construct a new laboratory in Cambridge. Biogen's co-founder, Dr Walter Gilbert, is also a professor of molecular biology at Harvard and was a strong critic of the university's proposed involvement in Genetics Institute.

Biogen is now discussing with the local council the terms under which it will be allowed to operate its laboratory. And the Cambridge Biohazards Committee and the Cambridge Experimental Review Board are discussing a revision to the 1977 ordinance which would require, among other things, that any company or laboratory involved in recombinant DNA research should implement a medical surveillance scheme and a registry of its workers.

Such provisions have already been proposed by the Department of Labor's National Institute of Occupational Safety and Health, on the grounds that any longterm, relatively low-level effects could be traced only if adequate exposure records are kept of laboratory workers and the substances they handle. Biogen has said that it would have little difficulty in meeting such a requirement. More controversial could be the suggestion of a public debate on the acceptability of the site proposed for the laboratory.

Some members of the review board are also hoping to persuade the council to demand independent approval of the safety measures adopted by the company. This might be done by employing a consultant who would report to the city council but whose services would be partly paid for by the company.

A local ordinance including several of the proposed requirements has already been passed by the city council of Waltham, Massachusetts, home of the company Collaborative Genetics. As in Cambridge, the ordinance - which also covers research at Brandeis University - is primarily designed to ensure that all local recombinant DNA research is carried out under the safety guidelines developed by the National Institutes of Health.
In some respects, however, the ordinance is stricter than the guidelines. For example, it requires a formal medical surveillance procedure and the maintenance of work records and also prohibits the use of recombinant DNA products for trials on human patients.

With this model before them, other cities - including Newton, home of New England Nuclear - which are considering their own ordinances may find it difficult to adopt stricter rules. $\mathrm{Mr}$ Hexler, for example, says that Genetics Institute would be pleased to live with the Waltham ordinance and that if Somerville is too restrictive, "Waltham is there and waiting".

David Dickson

\section{Lamont director quits}

\section{Washington}

Columbia University in New York has forced the resignation of the director of the university's Lamont-Doherty Geological Observatory, Dr Mark Talwani, after complaints from senior faculty members about a lack of effective leadership.

Dr Talwani was asked by the university to resign shortly before Christmas. The university's decision was based partly on a report on the situation at the observatory, one of the world's leading centres of oceanic and seismic research, prepared by an outside committee under the chairmanship of Dr Karl K. Turekian of Yale University.

According to the university, the report praised a number of accomplishments of the observatory, but notes the existence of "serious problems" with Dr Talwani's leadership.

The committee itself did not recommend that Dr Talwani be replaced. But after further review and consultation with senior faculty members, including a meeting in October at which "almost all the senior faculty" is said by the university to have supported the search for an alternative director, Dr Talwani was asked to resign within two weeks.

Talwani himself vigorously protested at the university's decision, claiming that it had been the product of a "conspiratorial approach", and complaining to the university trustees that because no specific charges had been levelled against him, "I have had no opportunity to defend myself".

He eventually submitted his resignation as director two weeks ago, although he will remain on the university faculty as a member of its department of geological sciences. A search committee has been established to recommend a successor, and is expected to make its recommendation within a few days. Meanwhile Dr Paul G. Richards, associate director of the observatory, has been temporarily appointed its chief executive officer.

David Dickson
Soviet fishing

\section{Whither whaling?}

The Soviet Far Eastern Fishing Fleet has ceased whaling operations in the Pacific, it was announced in Vladivostok last week. The three factory ships serving the fleet are now being converted into fish-processing plants.

This is the first stage in the implementation of a pledge given at the International Whaling Commission (IWC) meeting in California in December 1978. On that occasion, the Soviet delegate, Vyacheslav Zemskii, pledged his country to phase out all whaling within five years, starting with the North Pacific operation.

The announcement that three factory ships are being converted is, however, somewhat surprising. According to a Moscow radio broadcast shortly before the July 1980 IWC meeting, the Soviet Union had only two factory ships left, the Sovetskaya Rossiya and the Sovetskaya Ukrayina, both sailing from Vladivostok. Both of these ships, the commentator stressed, carried the necessary international observers as well as Soviet marine ecologists.

A partial phasing out of the North Pacific operation began some years ago. In 1979, when the Soviet Union accepted the IWC's partial moratorium, in which fishing from factory ships would be confined to Minke whales, it had already closed down its on-shore whaling stations, and had to negotiate an exchange with the Japanese, ceding its North Pacific quota of 230 Bryde whales in return for 300 of the less valuable Minke whales from the Antarctic.

The closedown of the North Pacific operation does not, however, necessarily mean that the Soviet Union will support the idea of a total moratorium. Soviet commentators have always taken the line that such a policy is not in accordance with the ecological facts, being based on a emotionalism encouraged by some quarters for political reasons. Greenpeace observers have described the Soviet whaling flotillas as near derelict hulks which would cost many millions of rubles to refit. This suggests that the planners have realized for some time that pro-moratorium pressure might well force the Soviet whaling flotillas to disband, and that it was not therefore cost effective to keep the ships in trim.

With the recent drive for self-sufficiency in raw materials, stressed at the October 1980 Central Committee Plenum and in the Guidelines for the new Five Year Plan, what will the Soviet Union use to replace whale-oil?. One possibility is the jojoba, which would probably thrive in the semiarid steppes of Soviet Asia. Unfortunately, the jojoba plant is dioecious, and, in the natural state, male plants predominate. Jojoba culture is therefore highly labourintensive, involving the vegetative propagation of large numbers of female 